\title{
Exemplarity and Its Discontents: Hellenistic Jewish Wisdom Texts and Greco-Roman Didactic Poetry
}

\author{
Hindy Najman and Tobias Reinhardt ${ }^{1}$ \\ University of Oxford, Oxford, UK \\ hindy.najman@oriel.ox.ac.uk; tobias.reinhardt@classics.ox.ac.uk
}

\begin{abstract}
This article sets up a dialogue between two bodies of ancient texts, i.e. Jewish wisdom literature and Greco-Roman didactic of the Hellenistic period, with an awareness of the scholarly and interpretive communities that have studied, taught and transformed these bodies of texts from antiquity until the present. The article does not claim direct influence or cross-pollination across intellectual, religious or social communities in the Hellenistic period. Instead, the article suggests four discrete frameworks for thinking about comparative antiquity: creation, the law, the sage and literary form. The comparative model proposed here intends to create the conditions for noticing parallels and kindred concepts. However, the article resists the temptation to repeat earlier scholarly arguments for dependency or priority of influence. Instead, the essay demonstrates remarkable alignments, suggestively similar developments, and synergies. Perhaps, the ideal first reader for this article is none other than Philo of Alexandria.
\end{abstract}

\section{Keywords}

Hellenistic Jewish wisdom texts - Latin didactic poetry - exemplarity

In this article we propose to compare and contrast two bodies of material which arose in chronological, geographical, and cultural proximity, which are

1 This paper was first presented at the Ethical Reading seminar in Oxford, and we acknowledge the commitments and questions of the participants as well as others who have read and contributed with incisive suggestions and editorial comments. In particular, we thank Arjen Bakker, Stefania Beitia, Annie Calderbank, Hans Decker, Jaś Elsner, Paul Franks, Constanze Güthenke, Shannon Parrott, Irene Peirano, Eibert Tigchelaar and Sarah Wisialowski.

(C) KONINKLIJKE BRILL NV, LEIDEN, 2019 DOI:10.1163/15700631-15051303 
thematically, formally, and pragmatically similar, but which have rarely been the subject of a close comparison: wisdom texts of the period ca. $400 \mathrm{BCE}$ to $100 \mathrm{CE}$ and Latin didactic poetry. ${ }^{2}$ We hope to advocate for a way of reading the two bodies of texts against one another, with particular attention to the fact that they promote exempla and rely on exempla for the articulation of their didactic content.

In recent years scholars of Hellenistic Greek and Roman didactic poetry have paid particular attention to the inner workings of the didactic tradition. This trend is in part motivated by a desire to isolate and delineate a distinctive didactic mode and to explore the tension between an intertextual approach (which has it that meaning is constructed in the act of reading) and the manifest intentio operis which many didactic texts exhibit, viz. the fact that a didactic text appears to convey a particular subject matter in a fairly regulated and controlled manner, thus closing down interpretive options when other poetic genres (e.g. lyric poetry) seem to invite them. As such, didactic texts represent an interesting space for developing and testing methodologies which can then be deployed in the study of other genres. ${ }^{3}$

With respect to Jewish wisdom literature, there are trends of research which consider the Hellenistic context for some of these wisdom texts. ${ }^{4}$ However, there is not yet significant work that considers texts from different cultural and religious contexts alongside each other. This essay suggests that this comparative approach can be mutually illuminating. And, while there are some modest beginnings to such work, it is ultimately underdeveloped in the field of Ancient Judaism and biblical studies more generally.

The absence of comparative work of the kind we propose here may be due to an assumption, widely held within our fields until fairly recently, that a modern reading of ancient texts should not be entirely divorced from ancient reading practices, i.e. should at a minimum be an interesting historical possibility if not an extension of a demonstrable historical actuality. We do not share this assumption, although we do believe that what we propose here might be worthwhile even on those narrow, historicist terms: we can think of possible ancient readers with the competence to anticipate our comparative work.

Wisdom texts and didactic texts rely on narrators who are uniquely knowledgeable, on accounts of valorised human behaviour (including abilities and

2 Cf., however, Schiesaro, "Lucretius' Apocalyptic Imagination" and "Lucretius' On the nature," which seek to identify parallels between Lucretius and Jewish apocalyptic texts. See also West, Hesiod, who discusses parallels to Hesiod's Erga from Babylonian, Egyptian, and Old Testament wisdom literature.

3 On Roman Didactic see Volk, Poetics; Kruschwitz and Schumacher, Lehrgedicht; Fowler, "Didactic Plot." On Vergil see Batstone, "Vergilian Didaxis"; on Manilius see Volk, Manilius.

4 Collins, Jewish Wisdom; Wright, "Ben Sira”; Najman, "Jewish Wisdom.” 
skills) and notably of wise men, but also on "other" texts (in the broader, semiotic sense of the term) that are held up for what they contain. Narrating and instructing in such an exemplary mode often requires what is to be emulated and what is discouraged to be juxtaposed and interlaced: promoting what is right often requires a contrast with what is wrong, or at least less good. In our exposition we have opted for a simple bipartite division of our material"exemplarity" and its "discontents" as it were. Although both aspects are almost invariably present together in our texts, which therefore militate against a simple binary hermeneutical scheme of endorsement and rejection, this has proved an effective way of organising our material.

We are, for various reasons, not aiming to demonstrate close formal correspondences, verbal or otherwise, and we would have cited them if our goal was e.g. to demonstrate the presence of one text in another on a conventional intertextual model. Rather, we are looking for broader thematic and pragmatic similarities. However, when we occasionally come across a couple of passages which do look strikingly similar, we will not refuse to acknowledge them.

Relatedly, while Greek and Roman didactic is a verse genre and while some wisdom texts have a poetic dimension or are even straightforwardly metrical, our interest in pragmatic similarities will mean that there will also be passages from wisdom texts that are best described as prose. The aim is not, of course, to show that wisdom texts are didactic poetry.

Texts conventionally called didactic include Hesiod's Theogony and Works and Days (Erga; ca. c. 8-7 BCE), the works of some Presocratic philosophers, notably Parmenides and Empedocles (c. 5 BCE), from the archaic period, as well as poems like Nikander's on snake bites (Theriaca) or Aratus' on constellations (Astronomica) in the Hellenistic period (c. 2 and c. 3 B CE, respectively). Important Roman works include Lucretius' De rerum natura on Epicurean philosophy, Vergil's Georgics on agriculture, as well as Ovid's Fasti on the Roman calendar, all dating from the first century BCE to the early first century CE. Most of these poems, across the literature/philosophy divide that is often applied to them, share certain features: a first-person narrator, one or more didactic addressees (e.g. a named individual addressed in the text and a broader readership), other formal characteristics (see section 3.4 below), as well as an aspiration to dispense knowledge, and to present the domain in which knowledge is to be conveyed either overtly as the world as a whole or as standing in for the world as a whole (in a manner which is cashed out in different ways depending on the text). 
Many though not all of the texts we are considering from the category of wisdom literature (e.g. Proverbs, Job, Ecclesiastes, Wisdom of Solomon, Ben Sira, but also Psalms, and Deuteronomy, as well as many texts from the Hellenistic period from the Dead Sea Scrolls and Pseudepigrapha) exhibit similar features. It should be noted that, like the category "didactic," that of "wisdom literature" is a scholarly construct. ${ }^{5}$ While the members of this body of work are indeed full of conversation about wisdom, the sage, and engage in proverbial discourse, the scholarship often glosses over aspects of this collection that do not fall under the category of "wisdom" and as a result loses a great deal of the complexity of the texts. ${ }^{6}$

The texts that fall under the category of wisdom texts are extant across linguistic boundaries: Greek, Hebrew, and Aramaic. Moreover, these texts overall are dedicated to describing the natural workings of the world and reflect on the passing of time in human life. In so doing, these texts thematise Wisdom herself as a divine consort and a conspiring force in the creation of the world (e.g. Prov 8).

The generic categories that have been set up as controls by scholars often obscure more than they illuminate. So, texts that have wisdom features are excluded from the discussion of wisdom literature because they do not appear in an explicitly "wisdom" collection or because they are rather liturgical or legal. ${ }^{7}$ Instead, it might be more profitable to allow for wisdom texts to be identified in a way so that they might also participate in other generic categories. ${ }^{8}$ Consideration of the Jewish wisdom traditions (in Hebrew, Greek, and Aramaic) from antiquity, alongside the Greek and Latin traditions, can problematise existing categories and sharpen lines of differentiation.

We would now like to introduce three passages from the tradition of "wisdom texts" whose similarity with the didactic tradition is so striking as hopefully to

5 See the helpful discussion by Weeks, "Useful Category?" A more radical stance is taken by Kynes, An Obituary.

6 Kister, "Relation to Other Genres."

7 For example, Crenshaw argues that biblical wisdom is a distinct literary corpus held together by an elusive "mysterious ingredient" that helps to bind it to the sages and distinguish it from other biblical writings. See Old Testament Wisdom, 4-11.

8 For further reflections on the use of generic categories in biblical studies, see Najman, "Idea of Biblical Genre." 
illustrate the promise of the entire comparative project. ${ }^{9}$ So although we do not offer a comparison in this section, we want to lay out Ben Sira's fundamental similarities to the didactic tradition.

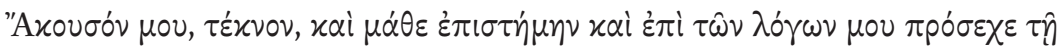

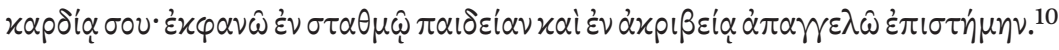

Listen to me, child, and learn knowledge, and to my words apply your heart. I will disclose instruction by fixed standard, and with accuracy I will declare knowledge.

BEN SIRA 16:24-25 (trans. Wright) ${ }^{11}$

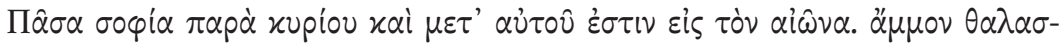

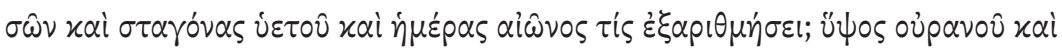

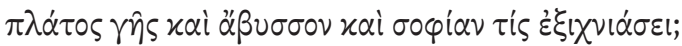

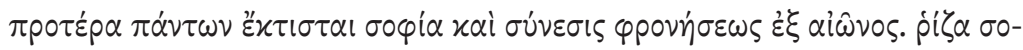

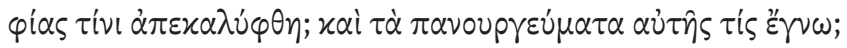

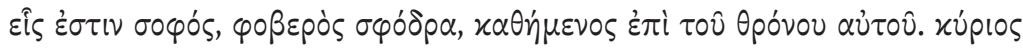

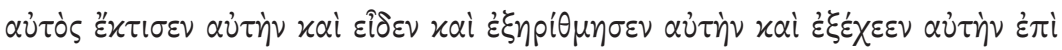

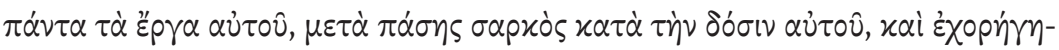

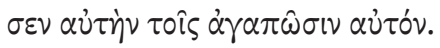

All wisdom is from the Lord, and with him it exists forever. Sand of seas and drops of rain and days of eternity — who shall enumerate? The sky's height and earth's breadth and abyss and wisdom — who will track?

Before all things wisdom has been created, and understanding of prudence is from eternity. Wisdom's root - to whom was it revealed? And her wondrous feats - who knew?

One who is wise, greatly feared, seated upon his throne. The Lord, he created her, and he saw and enumerated her and poured her out upon all his works, among all flesh, according to his giving, and he furnished her abundantly to those who love him.

BEN SIRA 1:1-10 (trans. Wright)

9 In this case, though not in others, we provide the Greek text as well, because of the close terminological similarities between the extracts and similar didactic texts.

10 Ziegler, Sapientia Iesu Filii Sirach.

11 In Pietersma and Wright, New English Translation. 


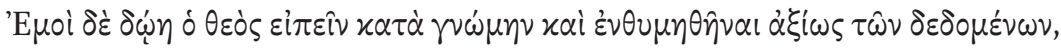

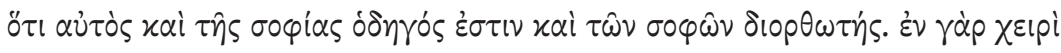

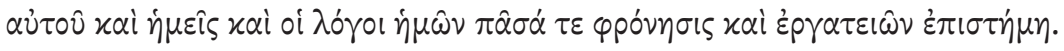

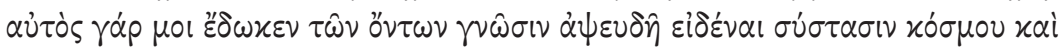

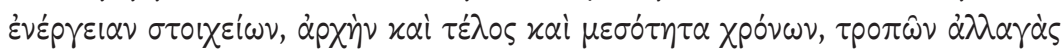

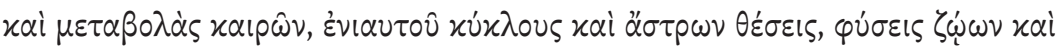

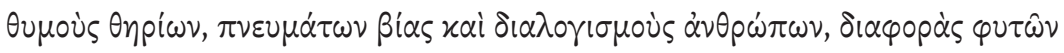

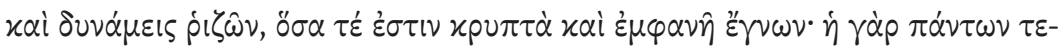

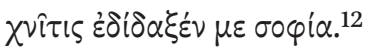

May God grant to me to speak with judgment and to think thoughts worthy of what has been given to me, because he himself is the guide even of wisdom and the corrector of the wise. For both we and our words are in his hand, both all understanding and skill in crafts. For he himself gave me an unerring knowledge of the things that exist, to know the constitution of the world and the activity of the elements, the beginning and end and middle of times, the alterations of the solstices and the changes of the seasons, the cycles of the year and the constellations of the stars, the natures of animals and the tempers of wild animals, the violent forces of spirits and the thoughts of human beings, the varieties of plants and the powers of roots, and all things, both what is secret and what is manifest, I learned, for she that is the fashioner of all things taught me, namely wisdom.

WISDOM OF SOLOMON 7:15-21 (trans. Knibb) $)^{13}$

Ben Sira 16:24-25 is a direct injunction to an addressee to attend to what is being said. It is also a first-person statement of didactic intent which hints at the text's immanent epistemology: what is to be conveyed conforms to a fixed and demanding standard, i.e. Torah or wisdom, and will be conveyed in an accurate manner, as opposed to, say, being more right than wrong but ultimately subject to human limitations. The addressee is dubbed a "child," which in didactic literature would be a conventional way to address the target audience, but Ben Sira contains passages which advise that children require different didactic approaches compared to adults (see section 4.2 below). Readers are thus bound to wonder in which sense of "child" they are being addressed and, consequently, which educational approach they are being subjected to. Encouragement of reflection on the didactic process while it is in progress is another feature students of didactic will recognise.

\footnotetext{
12 Ziegler, Sapientia Salomonis.

13 In Pietersma and Wright, New English Translation.
} 
Ben Sira 1:1-10 introduces "wisdom" not just as a disposition of intelligent beings, but also as a force which underwrites the world and its workings. Students of didactic are familiar with the notion that the world created in a given poem is governed by an underlying mechanism and possibly by a set of rules which is indirectly observable and which the teacher-narrator aims to expound and elucidate. But communicating the lesson is hard because the subject is vast and intricate, as lines 2-3 of the extract suggest.

Wisdom of Solomon 7:15-21 gestures to what we called a wisdom text's immanent epistemology above (which we take to be slightly different in each of the texts). It invokes divine support in a manner known from many a didactic poet, but this divine support is drawn on here for a different reason: it illustrates the domains over which wisdom texts range, which are strikingly like those to which didactic poems are devoted.

\subsection{Creation}

"Creation" narratives, or texts which thematically presuppose and rely on creation narratives, feature in both corpora, and their function is intriguingly similar: they position human beings, inevitably deficient and at best progressing, vis-à-vis a higher being that is perfect, eternal, and insightful in ways that human beings are not. They also situate human beings-as a group, i.e. not just the reader- "in history," inasmuch as they signal to the reader how she got to be in the situation that she finds herself in. Finally, they position the text itself in relation to other texts which feature creation narratives; as such, they represent a metaliterary gesture to "compare and contrast," to establish where this text is relative to others, what it claims compared to others. Yet the gesture is also one of assertiveness: of course the account proffered is right, and others are wrong, or at least less close to the truth.

Psalm 104 is formally a hymn which interacts with the first creation narrative in Genesis rather than the second (the earth and water are separated before the sun and the moon are created):;4 this is, as we shall see, rather similar to creation narratives embedded into didactic texts. The psalm exhibits a number of choices against a matrix of possibilities: it fills out details of God's creation in rich detail. God functions as creating subject and the world as created object, without an overt suggestion that God "resides" in the world thus created. There is a bipartite separation between the act of creation itself in

14 See recently, Van Wolde, "Separation and Creation." 
the remote past and the maintenance of the world and life in it in the present. Mankind is not characterised ethnically and is by implication treated as undifferentiated. There is artistic intent and poetic stylisation where the Genesis narrative is purely descriptive: in verses 6-9 God assumes the role of a warrior against the waters, and the waters are personified in the process. ${ }^{15}$

Proverbs 8 begins with a narrator's introduction to Wisdom, God's first creation, who takes her stand at the gates of the city and then launches into direct speech with numerous points of contact with Greco-Roman didactic poetry. Wisdom characterises herself in some detail, both as a physical principle and as part of a text-immanent epistemology, by situating herself in relation to numerous prima facie competing concepts (sound judgment, counsel, prudence). The creation narrative which she furnishes functions like a footnote to others, ${ }^{16}$ by identifying the relative point in time when wisdom was created and her assisting role in further creation. At the same time the embedding of the creation narrative in Wisdom's speech with its own introductory preface makes it manifestly part of larger contexts and raises the question how it relates to these contexts. One obvious function is to bestow authority on Wisdom, who delivers insights only God could have had at the time of creation (see below).

In Job 38:2-10 God appears as narrator and challenges man to recognise his limitations: the speaker enumerates various actions performed in the process of creation and describes them in the mechanistic language of craftsmanship. Man is invited to spell out what he can contribute to the account and whether he was present for some or all of creation. Read in a meta-literary way, this suggests that God did not just accomplish creation but also owns the creation narrative. A distinctive feature of the narrative is the use of birth imagery: the sea gushed forth out of its womb and is swaddled by the creator in dense clouds. ${ }^{17}$

Greco-Roman didactic has a need for creation narratives, too. These can be characterised with respect to two parameters, divine involvement vs. the absence of it, and moral progress vs. moral decline. Like the creation stories in wisdom texts, they look back to other, in some sense foundational texts on the same subject, which they may choose to endorse, qualify, or supplement. In his didactic poem on Epicurean philosophy, Lucretius wants to write divine influence out of the world as we perceive it and also out of the metaphysical structures underpinning it. In De rerum natura 5.793-808 the poet gives an account of

15 On the ancient Near Eastern background of this motif, see the classic study by Day, God's Conflict.

16 For the notion that a text might self-consciously function as a footnote to others, see Kerkhecker, Callimachus, 248 and 287-88.

17 For a discussion of some of the interpretive possibilities of this imagery, see Cornell, "God and the Sea." 
the creation of the species; this is explained in physical terms, in that the earth is warm and moist, and in suitable places, according to the account, wombs would grow in or upon the ground and be rooted to it. From these the various species would spring. Given the overall argument of De rerum natura, it is manifest that these lines need to be read against other creation narratives, ones which feature divine beings as creators. The passage combines a "historical" account with observations on the present, with the latter functioning as evidence for the former; these vistas on the present we encountered in Ps 104 as well. Lucretius also buys into motifs of fertility which could stand in the kind of narrative that is being countered, but they are subverted: that the warm and moist gives rise to living beings is cause rather than effect of creation. The notion of the womb is another obvious point of contact between Lucretius and Job 38:2-10.

A related thematic option in Greco-Roman didactic is the motif of the four ages of man. While this is not itself a creation narrative, in that it is concerned with the development of human civilisation when the world is already in existence, accounts of the four ages feature moments of creation, notably of particular species. In Vergil, Georgics 1.117-159 the gradual withdrawal of divine goodwill is the reason for the emergence of animals which are dangerous for human beings, and for the hostility of nature towards humans in general. As the environment gets more hostile, human ingenuity increases and progress occurs, but it is tainted by the fact that it is a coping mechanism and that the loss of divine support is not unmerited. What this kind of story does is, of course, delineate a human condition which forms the background against which instruction takes place. And in that respect it can be compared to embedded creation narratives in wisdom literature.

\subsection{Law}

Bound up with how creation is envisaged and how it matters that the world as it is has been created in a certain way is a notion of law, of ordering principles that operate in the world as it is, underwrite the ongoings in it, and can be grasped by human beings-provided, they have understanding and insight. Consider:

In the Lord's creation are his works from the beginning, and from the making of them he defined their portions.

He put in order their tasks forever and their rule for their generations;

they neither hungered, nor did they grow weary, and they did not abandon their tasks.

Each one did not crowd its fellow, and they will not ever disobey his dictum. 
And after these things, the Lord looked upon the earth, and he filled it with his good things.

With the soul of every living thing he covered its face, and into it is their return.

The Lord created a human being out of earth, and he returned him into it again.

He gave them days in number and a fixed time, and he gave them authority over the things upon it.

He clothed them in a strength like himself, and in his image he made them.

He placed the fear of him upon all flesh, even to have dominion over beasts and birds.

BEN SIRA 16:26-17:4 (trans. Wright)

Here the narrator characterises God's creation, the assignment of different spheres and capabilities, and crucially the fact that a finite amount of time is allotted to every generation and that it would be against the order thus imposed if generations did not succeed one another. ${ }^{18}$ The world overall is benign and everything is provided for, undoubtedly in part because of said changeover, which limits the call on the world's resources at any one time. Elsewhere in the text the human condition and the condition of creation generally is described in less optimistic terms, and the reader has to find a way to mediate: is the well-orderedness of the world qualified? Can goodwill temporarily be withdrawn? Is the apparent tension between certain passages due to a pragmatic difference (e.g. hymn vs. practical instruction)?

Here are two didactic texts which, in their own distinctive way, speak to the same subject.

You will also marvel that this custom has found favour with bees, that they indulge not in conjugal embraces, nor idly unnerve their bodies in love, or bring forth young with travail, but of themselves gather their children in their mouths from leaves and sweet herbs, of them- selves provide a new monarch and tiny burghers, and remodel their palaces and waxen realms. Therefore, though the limit of a narrow span awaits the bees themselves-for it never stretches beyond the seventh summer-yet the

18 On the theme of the divine determination of the times, see Von Rad, Wisdom in Israel, 263-83. See also Lange, Weisheit und Prädestination. 
race abides immortal, for many a year stands firm the fortune of the house, and grandsires' grandsires are numbered on the roll.

VERGIL, Georgics 4.197-209 (transl. Fairclough/Goold)

Besides, suppose that nature should suddenly utter a voice, and thus take her turn to upbraid one of us: "What ails you so, O mortal, to indulge overmuch in sickly lamentations? Why do you groan aloud and weep at death? For if your former life now past has been to your liking, if it is not true that all your blessings have been gathered as it were into a riddled jar, and have run through and been lost without gratification, why not, like a banqueter fed full of life, withdraw with contentment and rest in peace, you fool? But if all that you have enjoyed has been spilt out and lost, and if you have a grudge at life, why seek to add more, only to be miserably lost again and to perish wholly without gratification? Why not rather make an end of life and trouble? For there is nothing else I can devise and invent to please you: everything is always the same. If your body is not already withering with years and your limbs worn out and languid, yet everything remains the same, even if you shall go on to outlive all generations, and even more if you should be destined never to die." What have we to answer, but that nature urges against us a just charge and in her plea sets forth a true case?

But if in this regard some older man, well stricken in years, should make complaint, wretchedly bewailing his death more than he ought, would she not have reason to cry more loudly still and to upbraid in bitter words? "Away, away with your tears, ruffian, check your lamentations! All life's prizes you have enjoyed and now you wither. But because you always crave what you have not, and contemn what you have, life has slipped by for you incomplete and ungratifying, and death stands by your head unexpected, before you can retire glutted and full of the feast. But now in any case dismiss all that does not befit your age, and with equanimity, come now, yield to your years: thus it must be." She would be right, I think, to bring her charge, right to upbraid and reproach. For the old order always passes, thrust out by the new, and one thing has to be made afresh from others; but no one is delivered into the pit of black Tartarus: matter is wanted, that coming generations may grow; and yet they all, when their life is done, will follow you, and so, no less than you, these generations have passed away before now, and will continue to pass away. So one thing will never cease to arise from another, and no man possesses life in freehold - all as tenants. Look back also and see how the ages of everlasting time past 
before we were born have been to us nothing. This therefore is a mirror which nature holds up to us, showing the time to come after we at length shall die. Is there anything horrible in that? Is there anything gloomy? Is it not more peaceful than any sleep?

LuCretius, On the Nature of Things 3.931-977 (transl. Rouse/Smith)

The passage from Vergil's Georgics describes the well-organised society of the bees, itself provided and sustained by the forces which account for regularity in the natural world (a precondition for successful farming), although the creation of the bees itself was deemed a mystery. Bee society is anthropomorphised and in many ways better and more harmonious than human society; as in the wisdom texts, the contrast invites reflection. ${ }^{19}$ Like the Ben Sira passage the changeover of generations is emphasised, and one of the lessons delivered is that any pain and suffering arising from this fact is lessened if one chooses a sufficiently general frame of reference where the needs and wants of individuals recede into the background. The passage from Lucretius, the so-called speech of Nature, obviously invites comparison with speeches of Wisdom in wisdom literature: it is a moment of note in the narrative in both cases when the entity which is the subject of the poem is handed a direct speech (see below). For present purposes, however, we want to draw attention to the highlighted passage, which is just outside the speech and delivered by the narrator, yet in a manner which continues Nature's lesson: death is not to be feared and is to be yielded to willingly since generations must alternate. The reason cited is very much governed by Epicurean thinking: the material, i.e. the atoms which constitute our bodies and our soul, is needed to fashion new creatures (the atoms are only ever given "on lease" to individuals). This is a variation on a more conventional justification of the turnover of generations, and one in which this changeover occurs by divine provision and stipulation.

19 An explicit development of the same imagery can be found in the Septuagint Prov 6:8, where bees are used as an example of a high functioning society to serve as a call to the

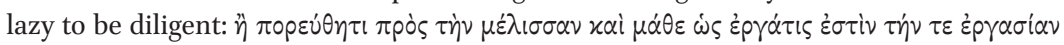

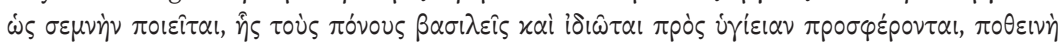

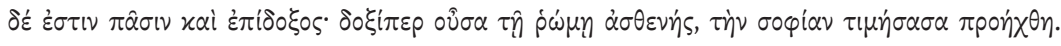
A similar reflection on apian society, which also uses language from Prov 6:8, is found in a small fragment from 4QInstruction: 4Q417 frag. 19. See Kister, "Wisdom Literature from Qumran," 312-13. 
3.3 The Sage

Both text corpora deploy the figure of a sage, i.e. of an idealised human being who embodies the particular text's values and outlook, who has a deep understanding, intuitive or otherwise, of what we have called "law" in the preceding section, and who can help the reader become an embodiment of such understanding. Consider:

Now Joshua son of Nun was filled with the spirit of wisdom because Moses had laid his hands upon him; and the Israelites heeded him, doing as the LORD had commanded Moses.

Never again did there arise in Israel a prophet like Moses-whom the LORD singled out, face to face, for the various signs and portents that the LORD sent him to display in the land of Egypt, against Pharaoh and all his courtiers and his whole country, and for all the great might and awesome power that Moses displayed before all Israel.

DEUT 34:9-12 (trans. JPS)

Moses' sagehood was recognised by the Lord who singled him out for it and entrusted him with responsibilities which would overwhelm any ordinary human being, but his wisdom was nonetheless transferable. What is more, Moses is an archetypal sage, privileged before others, whereas there are also lesser figures, who complement others (with whom they may feature in catalogues) and embody components of a larger concept of sagehood. ${ }^{20}$ See e.g. Sir 44:16-18 on Enoch and Noah:

Henoch pleased God, and he was changed, an example of repentance for generations.

Noe was found perfect, righteous; in a time of anger he became an exchange;

because of him, there was a remnant for the earth, when a flood occurred.

Covenants of eternity were added to him lest all flesh be blotted out by a flood. (trans. Wright)

20 These ideas are developed in different ways in Najman's Seconding Sinai and in "Jewish Wisdom." 
Compare Lucretius, On the Nature of Things 3.1-30:

O you who first amid so great a darkness were able to raise aloft a light so clear, illumining the blessings of life, you I follow, O glory of the Grecian race, and now on the marks you have left I plant my own footsteps firm, not so much desiring to be your rival, as for love, because I yearn to copy you: for why should a swallow vie with swans, or what could a kid with its shaking limbs do in running to match himself with the strong horse's vigour? You are our father, the discoverer of truths, you supply us with a father's precepts, from your pages, illustrious man, as bees in the flowery glades sip all the sweets, so we likewise feed on all your golden words, your words of gold, ever most worthy of life eternal. For as soon as your reasoning begins to proclaim the nature of things revealed by your divine mind, away flee the mind's terrors, the walls of the world open out, I see action going on throughout the whole void: before me appear the gods in their majesty, and their peaceful abodes, which no winds ever shake nor clouds besprinkle with rain, which no snow congealed by the bitter frost mars with its white fall, but the air ever cloudless encompasses them and laughs with its light spread wide abroad. There moreover nature supplies everything, and nothing at any time impairs their peace of mind. But contrariwise nowhere appear the regions of Acheron; yet the earth is no hindrance to all being clearly seen, whatsoever goes on below under our feet throughout the void. There upon from all these things a sort of divine delight gets hold upon me and a shuddering, because nature thus by your power has been so manifestly laid open and uncovered in every part. (transl. Rouse/Smith)

Deploying the format of a hymn, and ascribing to Epicurus super-human feats, Lucretius holds up Epicurus as a model to emulate and copy. Lucretius goes so far as to project onto Epicurus properties and activities which properly belong to himself as the poet narrator, deploying poetological metaphors to describe Epicurus' prose writings. And although it was a key component of Epicurus' teachings to write the gods out of the world by assuming that they were physically, emotionally, and intellectually completely detached from human life, Lucretius deploys religious language to characterise Epicurus' achievement.

Contrast Vergil, Georgics 4.116-148:

In fact, were I not, with my task well-nigh done, about to furl my sails and making haste to turn my prow to land, perchance I might sing 
what careful tendance clothes rich gardens in flower, and might sing of Paestum whose rose beds bloom twice yearly, how the endive rejoices in drinking streams, the verdant banks in celery; how the cucumber, coiling through the grass, swells into a paunch. Nor should I have passed in silence the late-flowering narcissus, the twining tendril of the acanthus, pale ivy sprays, or the shore-loving myrtle. For I call to mind how once under the towers of the Oebalian citadel, where dark Galaesus waters the yellowing corn, I saw an old Cilician, who occupied a few acres of unclaimed land, not rich enough for ploughing, nor fit for pasturage, nor suited to the vine. Even so, planting cabbages here and there among the brambles, and white lilies and vervain and fine-seeded poppies, in happiness he equalled the wealth of kings, and returning home late at night he used to load his table with an unbought banquet. First he was in the spring to gather roses, and apples in the fall; and when grim winter was still bursting rocks with her frost and braking the current of rivers with ice, already he was cutting soft-haired hyacinths and chiding laggard summer and the loitering zephyrs. Thus it was that he was still the first to be enriched with teeming bees and a plenteous swarm, and first to gather from the squeezed comb the frothing honey; his limes and laurestines were ever luxuriant, and all the fruits which clothed his fertile trees in their early blossoming, so many they kept in the ripeness of autumn. He would also plant out elms in rows, though late in season, pears when quite hard, blackthorns already hung with sloes, and planes already offering to drinkers the service of their shade. But all this I must pass by, constrained by narrow bounds, and leave to others after me to record. (transl. Fairclough/Goold)

Here Vergil describes an old man, the Corycian senex, who embodies successful and apparently effortless farming and is as such emblematic of the subject matter the poet seeks to convey. At the same time, in terms of the space he demands, he is a minor figure who makes his sole appearance in this passage, like the brief glimpses of the lesser sages offered in wisdom texts. Modern readers have seen a deliberate contrast with Epicurus as eulogised by Lucretius, a notion which-once conceived-leads to the identification of points of contact and contrast between the two passages. The late-antique commentator Servius (Comm. in Georg. 4.127) informs us that the senex was a former pirate, i.e. someone who had left behind a troubled life and exchanged it for the idyllic state described by Vergil. We have no reason to think that Vergil was thinking of a particular historical human 
being, or that Servius, writing four hundred years after Vergil, had any insider knowledge. Rather, instruction by exemplar abhors a vacuum, and if we are to emulate and to follow, a certain amount of back story is required and naturally supplied.

\subsection{Form}

3.4.1 The Addressee

Above we mentioned already similarities in the manner in which addressees are constructed in both corpora. ${ }^{21}$ We saw that in Sir 16:24-25, quoted above, the audience is addressed as "child" ( $\tau \dot{\varepsilon}$ xvov), which might be deemed a semantically empty formality and as such of no consequence to how the reader should conceive of the narrator-reader relationship, of the process of instruction, and of any persuasive or instructional technique the narrator employs. However, there are other passages (a) which address the readership as someone's children, though they need not be small, (b) which appear to cast the readership as younger and as being addressed in an age-appropriate manner, and (c) ones which are about the right way of dealing with children.

On (a), see Sir 3:1-4 and 12-13:

Listen to a father's reproof, children, and act accordingly so that you may be safe.

For the Lord has glorified father over children, and has confirmed a mother's judgment over sons.

He who honors father will atone for sins, and like one who lays up treasure is he who glorifies his mother.

Child, support your father in old age, and do not grieve him during his life.

But if he fails in comprehension, excuse him, and do not dishonor him in the fullness of your strength. (trans. Wright)

On (b), see Sir 6:23-36:

Listen, child, and accept my opinion, and do not reject my counsel.

21 On the subject see Schiesaro et al., Mega Nepios. 
Put your feet into her [i.e. wisdom's] fetters, and into her collar, your neck.

Offer your shoulder, and carry her, and do not be offended at her bonds.

With all your soul approach her, and with all your might keep her ways.

Trace, and seek, and she will become known to you, and when you get a firm hold, do not let her go.

For in the end you will find her repose, and she will be changed into gladness for you.

And her fetters will be a shelter of strength for you, and her collars a robe of glory.

If you are willing, child, you will be instructed, and if you surrender your soul, you will be clever.

If you listen, you will receive, and if you incline your ear, you will be wise.

Stand in a crowd of elders, and cling to their wisdom. (trans. Wright)

On (c), see Sir 30:1-2, 9-12:

He who loves his son will persists in whipping him, so that he may be glad at his outcome.

He who instructs his son will profit by him, and among acquaintances he will boast about him.

Coddle a child, and it will terrorize you, play with him, and he will grieve you.

Do not laugh together with him, lest you suffer together, and in the end you will gnash your teeth.

Do not give him license in his youth, [and do not overlook his ignorances.]

[Bend his neck in youth.]

Bruise his sides while he is an infant, lest, when he becomes stubborn, he will disobey you. (trans. Wright) 
Now compare Lucretius $1.935^{-95}$, which is preceded by a characterisation of Lucretius' intention and of the subject matter he seeks to convey while casting it into purportedly suitable and helpful poetic form:

... but as with children, when physicians try to administer rank wormwood, they first touch the rims about the cups with the sweet yellow fluid of honey, that unthinking childhood be deluded as far as the lips, and meanwhile may drink up the bitter juice of wormwood, and though beguiled be not betrayed, but rather by such means be restored and regain health, so now do I: since this doctrine commonly seems somewhat harsh to those who have not used it, and the people shrink back from it, I have chosen to set forth my doctrine to you in sweet-speaking Pierian song, and as it were to touch it with the Muses' delicious honey, if by chance in such a way I might engage your mind in my verses, while you are learning to see in what shape is framed the whole nature of things. (transl. Rouse/Smith)

The Lucretius passage had traditionally been interpreted as a window into the writer's mind, indicating how he conceived of the relationship between the content of his work and its poetic form: bitter medicine which is good for us, coated in honey to trick us into taking the medicine. Some years ago it was suggested that the rhetoric of the passage and consequently its didactic aims may actually work somewhat differently: ${ }^{22}$ by casting the readership as naive children who need to be tricked into doing what they ought to want themselves, the didactic narrator may be issuing an implicit invitation to identify with him rather than the children, to side with him, and to accept the philosophical teachings in the process. ${ }^{23}$ Another well-known feature of Lucretius' text is the so-called fading of the implied addressee, viz. the fact that there is an individual, identified by name, who is initially being addressed and whose needs are apparently being catered for, but whose presence then reduces and gives way to a generic addressee, raising the question for the reader when they have been promoted from bystander to primary recipient.

If we now turn to the Ben Sira extracts, we observe that the narrator shifts between passages addressed to, apparently, an adult, mature and rational audience (addressed as child) and passages where either the same audience qua

\footnotetext{
22 See Mitsis, "Committing."

23 Anne Stewart develops a similar comparison between Lucretius and the book of Proverbs in her discussion of didactic strategies. See Poetic Ethics, 55-61.
} 
someone's children or even younger persons are being instructed. ${ }^{24}$ In addition, there are passages which advise on the treatment of children: tough love, simple messaging, instruction rather than reasoned argument. How is the reader to react? Surely the question must arise from time to time in what sense of "child" one is being addressed, and if the conclusion is that the narrator is dispensing instruction in a manner which is at odds with the self-conception of the reader, will the latter react by considering themselves duly put in their place, by "siding" with the instructor, or in yet another way? Manipulation of the internal addressee is apt to induce reflective reading at the point of reception, whether or not the author intended it. In any event, we suggest that the construction of the addressee in both corpora invites comparison.

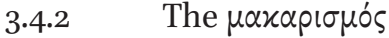

Another shared formal feature is the $\mu \alpha x \alpha p ı \mu \operatorname{sos}^{25}$ See e.g. Sir 25:8-10:

Happy is he who dwells with a sensible wife and who did not slip with the tongue and who did not become a slave to one unworthy of himself.

Happy is he who found prudence, and he who recounts to the ears of people who listen.

How great is he who finds wisdom, but there is none above him who fears the Lord. (trans. Wright)

Also Prov 8:32-36 [Wisdom speaking]:

Now then, my son, listen to me.

Happy is the man who will listen to me and the person who will guard my ways, keeping watch at my doors daily, protecting the posts of my entrances.

For my egressions are the egressions of life,, and the incentive is prepared by the Lord.

But those who sin against me treat their own souls with impiety, and those who hate me love death. (trans. Cook) ${ }^{26}$

\footnotetext{
24 See Wright, "Generation to Generation."

25 See Norden, Agnostos Theos, 99-101.

26 In Pietersma and Wright, New English Translation.
} 
Vergil, Georgics 2.457-499, of which we only give lines 490-499:

Blessed is he who has succeeded in learning the laws of nature's working, has cast beneath his feet all fear and fate's implacable decree, and the howl of insatiable Death. But happy, too, is he who knows the rural gods, Pan and aged Silvanus and the sisterhood of the Nymphs. Him no honours the people give can move, no purple worn by despots, no strife which leads brother to betray brother; untroubled is he by Dacian incursion swooping down from a Danube leagued in war, untroubled by Rome's policies spelling doom to kingdoms; if he has not felt pity for the poor, he has never envied the rich. (transl. Fairclough/Goold)

The $\mu \alpha$ карı $\sigma$ ós is a device which attracts-or naturally lends itself-to programmatic statements, and that it is used in all sorts of texts including our two corpora is well understood. However, it acquires special functions and resonances when employed in texts which intend to instruct. The Ben Sira extract compresses an idealised human condition, characterised with reference to prudence, wisdom, and the Lord, into four lines. ${ }^{27}$ Wisdom's words are the peroratio of her speech in Prov 8. And Vergil, in a self-conscious use of the feature, contrasts more than one conception of life in a string of $\mu \alpha \kappa \alpha p$ to the reader to work out the relationship between them.

\subsubsection{Speeches by the Personified Main Character}

We noted above that direct speeches by Nature and Wisdom, i.e. by the "central character" of the narrative, make for an important moment in our texts. Lucretius' didactic poem is full of passages in which teachings are read of nature, in such a way that events in the perceptible world are explained in terms of their underlying atomic structure. It is thus striking, though entirely explicable in terms of the internal logic of the surrounding context, that, when Nature comes to speak herself at the end of book 3 , she has no teachings to offer on the reality of the atoms which underpins the world (and it is, as we saw, left to the narrator to make this particular connection). Instead she speaks of the right attitude human beings should adopt towards death, thereby signalling that all the effort spent on physical explanation is not an end in itself and driven, as it might be, by a basic human desire "to find out," but by an ethical purpose. ${ }^{28} \mathrm{We}$ had quoted and considered Prov 8 above; add Sir 24:1-17:

\footnotetext{
27 Puech, "Béatitudes."

28 Lucretius' Natura has been compared to П飞vi $\alpha$ in Bion of Borysthenes (frag. 17 Kindstrand), who was also personified and given a direct speech. "Poverty" is a key ideological concept
} 
Wisdom will praise her soul, and in the midst of her people she will boast.

In an assembly of the Most High she will open her mouth, and before his power she will boast.

"I came forth from the mouth of the Most High, and like a mist I covered earth.

I encamped in the heights and my throne was in a pillar of cloud.

A circle of sky I encircled alone, and in the deep of abysses I walked.

In the waves of the sea and in all the earth and in every people and nation I led.

With all these I sought repose, and in whose inheritance I would settle.

Then the creator of all commanded me, and he who created me put down my tent

and said, 'Encamp in Iakob, and in Israel let your inheritance be.'

Before the age, from the beginning, he created me, and until the age I will never fail.

In a holy tent I ministered before him, and thus in Sion I was firmly set.

In a beloved city as well he put me down, and in Ierousalem was my authority.

And I took root among a glorified people, in the portion of the Lord is my inheritance.

Like a cedar I was raised up in Lebanon, and like a cypress in the mountains of Aermon.

Like a palm I was raised up in Aiggada, and like rosebushes in Iericho,

like a good-looking olive tree in a plain, and I was raised up like a plane tree.

Like cinnamon and camel's thorn for spices, and like choice myrrh I gave forth a fragrance,

like galbanum and onycha and stacte and like the vapor of frankincense in a tent.

for the genre in which Bion wrote, dubbed "diatribe" by modern scholars; diatribes offer instruction in a popular mode. Compare also Manilius' personification of Gloria in Astr. 2.808-19, whose decrees are, however, reported by the narrator. 
I, like a terebinth, spread out my branches, and my branches were branches of glory and grace.

I, like a vine, budded forth favor, and my blossoms were the fruit of glory and wealth. (trans. Wright)

Wisdom, ostensibly the subject of the whole text, verbalises her own reach here and describes - the Lord's first creation that she is - her allocated role in the world. She introduces the Lord in a direct speech of his own, enacting their connection. And as the extract progresses she becomes more poetic in tone, ending on a string of comparisons which illustrate her properties. ${ }^{29}$

\subsubsection{The Catalogue}

Another formal feature in evidence in both corpora is the catalogue, a fairly rapid collection of significant figures who may either serve as straight exemplars, may complement one another and thus be partial exemplars, or else be significant figures for the didactic project that is being pursued, for better or worse. We begin with Sir 44:1-45:5:

44:1Let us now praise famous men and our fathers by descent.

The Lord created much glory, his majesty from eternity.

When they ruled in their kingdoms, men also became noteworthy through power;

when they counseled with their intelligence, when they announced through prophecies,

${ }^{4}$ when they led people by deliberations and with understanding of a people's scribal artwise words there are in their instructionwhen they searched out musical tunes and set out verses in writing rich men well endowed with strength, being at peace in their dwelling-placesall of these were glorified in generations and in their days were a boast.

${ }^{8}$ There were some of them who left behind a name so that their praises might be told in detail.

29 On the usage of cross-cultural metaphors for wisdom in Sir 24, see Newman, "Hybridity, Hydrology." 
And of others there is no memorial, and they perished as though they had not existed, and they became as those who had not been born, and their children after them.

${ }^{10}$ These, on the other hand, were men of compassion, whose righteous deeds were not forgotten.

With their seed it will remain; a good inheritance is their offspring.

In the covenants their seed stood, and their children for their sake.

Forever will their seed remain, and their glory will not be blotted out.

Their bodies were buried in peace, and their name lives for generations.

${ }^{15}$ Peoples will recount their wisdom, and an assembly will proclaim their praise.

${ }^{16}$ Henoch pleased God, and he was changed, an example of repentance for generations.

Noe was found perfect, righteous; in a time of anger he became an exchange;

because of him, there was a remnant for the earth, when a flood occurred.

Covenants of eternity were added to him lest all flesh be blotted out by a flood.

${ }^{19}$ Abraam was a great father of a multitude of nations, and no blemish was found on his glory,

who kept the law of the Most High, and he entered in a covenant with him;

in his flesh he established a covenant, and in a trial he was found faithful.

Therefore he established by means of an oath with him that nations would be blessed by his seed, that he would multiply him as the dust of the earth and like the stars to exalt his seed and to give them an inheritance from sea to sea and from the river to the end of the earth. And with Isaak he likewise established, on account of Abraam his father.

A blessing for all humankind and a covenant ${ }^{23}$ he put down upon the head of Iakob; 
he acknowledged him with his blessings, and he gave to him by an inheritance,

and he divided his portions, and he allotted among twelve tribes.

And he brought out of him a man of mercy, who found favor in the eyes of all flesh,

45:1 who was loved by God and human beings,

Moyses, whose memorial is accompanied by blessings.

He made him equal to the glory of holy ones, and he made him great by terror for enemies.

By his words he hastened signs;

he glorified him in front of kings;

he gave him commands for his people, and he showed him his glory.

In faithfulness and meekness he consecrated him; he chose him out of all flesh.

He caused him to hear his voice, and he led him into the deep darkness, and he gave him commandments face-to-face, a law of life and knowledge,

to teach Iakob a covenant and Israel his judgments. (trans. Wright)

Manilius, Astronomica 1.758-776:

Perhaps the souls of heroes, outstanding men deemed worthy of heaven, freed from the body and released from the globe of Earth, pass hither and, dwelling in a heaven that is their own, live the infinite years of paradise and enjoy celestial bliss. If so, here we honour the line of Aeacus, here the sons of Atreus, and warlike Diomede; the man of Ithaca, too, who by his triumphs on land and sea was nature's conqueror; the Pylian, renowned for a long life of triple span, and the other Greek chiefs who fought at Troy; Hector, bulwark and glory of the Ilian race, together with Aurora's dusky son and him of the Thunderer's stock who ruled Lycia; nor let me pass you by, Amazonian maid, and the other kings sent by Thrace, the nations of Asia, and Pella, whose greatest glory lies in him called Great. Nor must I fail to mention the sages, strong of mind, men of exact and weighty judgement, who in their own selves possessed every endowment: the upright Solon and resolute Lycurgus; the inspired Plato and the man who had fashioned him, whose condemnation served rather to 
condemn his native Athens; and the conqueror of Persia, the land whose fleet covered the sea. (trans. Goold) ${ }^{30}$

Ben Sira 44:1-15 praises famous men as God's creation and ancestors of the audience. ${ }^{31}$ Praising them for their qualities is thus continuing the delivery of instruction and at the same time improving the receptiveness of the audience, because there is a sense that it is their story that is being told unlike in some of the sections which expound on Wisdom. Verses 4-7 signal the fact that the men in question are an independent source of insight into wisdom, as their achievements were recorded for our benefit in various ways, which is, presumably, where the narrator's insight into them comes from. Relatedly, such men need someone who memorialises them for their achievements and their lessons to endure (verses 8-15). Ben Sira 44:16-23 and chapter 45 then introduces wise men by name, who are each singled out for a set of admirable qualities, except for Moses, whom God singled out.

Lucretius 1.635-920, which we have not quoted, provides a catalogue-like section of intellectual predecessors in book 1 of De rerum natura. In line with his general tendency to subvert the tradition he is part of, two of these predecessors are dismissed for their supposedly ridiculous views, but Empedocles is a different case: he is an important literary model for Lucretius, and although Lucretius cannot accept his views as correct, he suggests that nature impinged on him so as to influence the formulation of his views. This is significant because the Epicureans thought that their doctrines were derived from and in some sense read off nature. A point of contact with the wisdom texts is that the secondary exemplar cited, i.e. Empedocles, allows for insight into the worldshaping power (here Nature, there Wisdom) which is the subject of the overall narrative, yet by a different route.

Manilius, in lines 1.758-804 of the Astronomica (of which we have quoted a part), ends a series of four explanations of what the Milky Way is with a fifth one, which he actually favours: the Milky Way is made up from the souls of distinguished men, which he proceeds to enumerate. This explanation is not attested elsewhere in astrological literature, and is most likely developed from a passage in Cicero's De re publica, i.e. Somn. Scip. 16. While the circumstances which govern Manilius' choices in many cases are peculiar to him and the concerns of his poem, the didactic technique which he employs once again is comparable to what we have seen before: the prestige and standing of the famous

\footnotetext{
30 Goold, Manilius.

31 On the interpretive traditions in Ben Sira's hyms of praise, see Wright, "Use and Interpretation."
} 
men whom he mentions is what lends his favoured explanation credibility, in a manner which a rational argument could not deliver: we would like to believe that the souls are famous men who have gone to heaven. The catalogue is a tool for inducing credence: its power derives from the fact that it delivers authority by a route that is independent from the main narrative.

The narrator (or narrators) in wisdom texts often assume the perfect implementation of wisdom in the world and on earth as a state, so that it might seem that earth can approximate the heavens. This might give the impression of an easy or at least achievable correspondence between what is desired and what can be achieved by the reader who wants to progress. In the same way, the didactic texts offer plenty of moments where the well-orderedness of the world, on the level of description on which they focus, is assumed and described, and progress towards genuine understanding seems if not straightforward then at least achievable.

However, it is no coincidence that the same texts at times emphasise, alongside the possibility, the impossibility of overcoming one's own humanity. There is a fundamental recognition of human limitation in both of our corpora which ultimately characterises human beings as incomplete. The teachings which our texts purport to deliver need to combine hopeful encouragement and unvarnished warning, either of the difficulties which might hamper progress, or of the imperfect situation from which we start in search of remedy. Relatedly, they present the world at times as chaotic or at least as inhospitable to human life, which obviously places a constraint on human progress. If this point was merely deployed to convey that progress requires genuine effort and application, then this would be unsurprising. However, there are also moments of such profound pessimism in our texts that a different explanation seems to be required.

\subsection{Human Weakness}

Consider Wisdom of Solomon 9:9-18:

${ }^{9}$ With you is wisdom, which knows your works and was present when you made the world and understands what is pleasing in your eyes and what is right according to your commandments.

Send her out from the holy heavens, 
and from your glorious throne send her, that, being present with me, she may labor with me and that I may learn what is well-pleasing before you, for she knows all things and understands them and will guide me prudently in my actions and guard me with her glory. Then my deeds will be acceptable, and I will judge your people justly and be worthy of the throne of my father. ${ }^{13}$ For what human being can learn divine counsel? Or who can conceive what the Lord wills? For the thoughts of mortals are worthless, and our inventions liable to fail. For a corruptible body burdens the soul, and the earthly tent weighs down a mind full of cares. With difficulty we make inferences about what is on earth, and what is at hand we find with labor, but who has traced out what is in the heavens? Who has learned your counsel unless you gave wisdom and sent your holy spirit from on high? And thus the ways of those on earth were set right, and human beings were taught what is pleasing to you and were saved by wisdom. (trans. Knibb)

Verses 9-12 address God and ask for Wisdom to be sent, whom the narrator extols and whose support he hopes to rely on. Verses 13-18 then furnish reasons why human beings are in need of such assistance: they struggle to make use of unmediated counsel from God, they lack insight and possibly intelligence, and their attempts at resolving difficulty are often unsuccessful. This is because their epistemic and cognitive position is compromised. The narrative then returns to the need for Wisdom to assist and mediate.

The following two extracts from the Dead Sea Scrolls Thanksgiving Hymns (Hodayot) speak to the flaws and weaknesses of human beings.

[... by] your plan eve[rything] comes to be, [and] in the intent of your mind it is de[ter]mined. [Apart from you no]thing [is done,] and without your will nothing comes to pass. No one can contemplate [your], wis[dom], and on your [secret] mysteries no one can gaze. What, then, is a mortal being-he is only dirt, pinched-off c[lay], whose 
return is to dust - that you have given him insight into wonders such as these and that the secret counsel of [your] tru[th] you have made known to him?

As for me, dust and ashes, what can I devise unless you desire it, and what can I plan for myself without your will? How can I take courage unless you cause me to stand firm? And how can I have insight unless you have formed it for me? What can I say unless you open my mouth? And how shall I answer unless you give me insight?

Behold, you are the prince of gods, the king of the glorious ones, lord of every spirit, and ruler of every creature. Apart from you nothing is done; nothing is known without your will; and except for you, there is nothing. There is none beside you in strength, none comparable to your glory, and for your strength there is no price. Who among all your wondrous great creatures can retain the strength to stand before your glory? And what, then, is he who returns to his dust that he could summon such strength? For your glory alone you have done all these things.

1QH ${ }^{\mathrm{a}}$ 18:3-14 (trans. Newsom)

These things I know because of understanding that comes from you, for you have opened my ears to wondrous mysteries. Yet I am a vessel of clay and a thing kneaded with water, a foundation of shame and a well of impurity, a furnace of iniquity and a structure of sin, a spirit of error, and a perverted being, without understanding, and terrified by righteous judgments. What could I say that is not already known, or what could I declare that has not already been told?

$1 \mathrm{QH}{ }^{\mathrm{a}}$ 9:23-25 (trans. Newsom)

While $1 \mathrm{QH}^{\mathrm{a}}$ 18:3-14 holds out hope for human beings to progress if they hand themselves over to God and allow themselves to be guided, $1 \mathrm{QH}^{\mathrm{a}}$ 9:23-25 creates the impression that the narrator could in no way act and speak on behalf of God given his human limitations. ${ }^{32}$ One might even want to argue that this is connected to the prohibition against making images.

The didactic tradition is, when issuing instructions, keenly aware of human mortality, fragility, and misguided behaviour, which jointly act as a constraint on the didactic enterprise. Different texts offer different diagnoses of course,

32 It is worth noting a transformative reworking and integration of Ps 8 and Job 7. These two texts, amongst others, are reworked and transformed in a new liturgical context which exemplifies the wisdom tradition but now in a liturgical form. 
i.e. offer different accounts of the origin of whatever ills routinely befall humans. Here is Lucretius 3.59-93 on non-Epicureans:

Moreover, avarice and the blind lust of distinction which drive wretched men to transgress the bounds of law, and sometimes by sharing and scheming crime to strive night and day with exceeding toil to climb the pinnacle of power, these sores of life in no small degree are fed by the fear of death. For in general degrading scorn and bitter need are seen to be far removed from sweetness and stability of life, and a lingering as it were before the gates of death; from which men desiring to escape afar and to remove themselves far away, driven by false terror, amass wealth by civil bloodshed and greedily multiply riches, piling murder upon murder; cruelly they rejoice at the mournful death of a brother, they hate and they fear a kinsman's hospitality.

In like manner and through the same fear, they are often consumed with envy that before their very eyes he is clothed in power, he is the sight of the town, who parades in shining pomp, while they complain that they themselves are wallowing in darkness and mire. Some wear out their lives for the sake of a statue and a name. And often it goes so far, that for fear of death men are seized by hatred of life and of seeing the light, so that with sorrowing heart they devise their own death, forgetting that this fear is the fountain of their cares: it induces one man to violate honour, another to break the bonds of friendship, and in a word to overthrow all natural feeling; for often before now men have betrayed fatherland or beloved parents in seeking to avoid the regions of Acheron. For as children tremble and fear everything in the blind darkness, so we in the light sometimes fear what is no more to be feared than the things that children in the dark hold in terror and imagine will come true. This terror, therefore, and darkness of the mind must be dispersed, not by rays of the sun nor the bright shafts of daylight, but by the aspect and law of nature. (transl. Rouse/Smith)

This passage explains ambition and various types of moral transgression as motivated by fear of death. One might think that Lucretius is talking about ambitious and powerful individuals in particular, but his diagnosis of the human condition assumes that all non-Epicureans suffer from versions of what is described. In a number of ways these explanations of misguided behaviour are predicated on distinctive tenets of Epicurean philosophy and as such peculiar to the didactic project Lucretius is pursuing. However, the distinction between 
the corruptible body and the soul in the passage from Wisdom of Solomon above represents a similarity in kind.

Fowler has, in a manner which will be deeply familiar to students of Lucretius, used a chart to represent the nexus of anxieties and consequently patterns of behaviour of which the poet tries to cure the reader. ${ }^{33}$ Most of the wisdom texts would see fear of God as a positive, civilising force, and as indicated the Epicurean outlook is in this respect peculiar, but all of the texts from both corpora embed a conception of the weaknesses of human beings, and it is an appropriate response on the part of the reader to try and extract something approaching a diagnosis of the human condition, so as to be able to absorb the text's lessons. In general, a text in which a narrator aims to teach a competence will end up talking about falling short and will therefore have to theorise falling short in some way.

\subsection{The World is Flawed}

Then there is Eccl 1:12-14, which speaks to the flaws of the world we inhabit rather than our own limited abilities of making progress:

I, Koheleth, was king in Jerusalem over Israel. I set my mind to study and to probe with wisdom all that happens under the sun.-An unhappy business, that, which God gave men to be concerned with! I observed all the happenings beneath the sun, and I found that all is futile and pursuit of wind: A twisted thing that cannot be made straight, a lack that cannot be made good. (trans. JPs)

This text, which stands out within the tradition because of its extreme pessimism, appears to foreclose any prospect of progress and self-improvement under guidance from either God or Wisdom. This view of the human condition is presented as a point of arrival after extensive enquiry.

Compare Lucretius, On the Nature of Things 5.195-217:

But even granting that I did not know what are the first-beginnings of things, thus much at least I would dare to affirm from the very ways of heaven, and to show from many other facts, that the world was certainly not made for us by divine power: so great are the faults with which it stands endowed.

In the first place, of all that the sky covers with its mighty expanse, a greedy part is possessed by mountains and forests full of wild beasts,

33 Fowler, "Lucretius," 137. 
part rocks and vasty marshes hold, and the sea that keeps the shores of lands far apart. Almost two parts of these lands are robbed from mortals by scorching heat, and constantly falling frost. Even the land that is left, nature would still cover with brambles by her own power, but that man's power resists, well accustomed to groan over the stout mattock for very life, and to cleave the soil with the pressure of the plough. If by turning over the fruitful clods with the ploughshare and trenching the soil we do not bring them to birth, no growths could emerge into the lambent air of their own accord; and even so at times, these procured by great labour, when they are already covering the earth with leafage and are all in bloom, are either scorched up by the sun in heaven with too great heat, or cut off by sudden rains and chilly frost, and the blasts of wind batter them with violent storms. (transl. Rouse/Smith)

According to this extract, large parts of earth are hostile to human beings and any attempt to cultivate the land and grow crops requires considerable effort. This is cited against the view that the earth was created by divine providence for the benefit of humans. What is more, rather than to present the world as inhospitable in a matter of fact sort of way, there is a suggestion of agency: nature made the world as it is. Mansfeld has seen hints of the bad demiurge known from Gnosticism here. ${ }^{34}$ There are also famous passages in Vergil's Georgics which characterise human life as toil and struggle, although they offer different explanations for it.

\subsection{Deviant Forms of Wisdom}

And just as it may be desirable in terms of narrative logic to draw attention to the inherent incompleteness and weaknesses of human beings, or to the fact that the world does not actually give the appearance of being providentially organised for the benefit of human beings, so the narrative may want to create a space for deviant forms of wisdom and the figures who represent them. These figures may either claim or be credited by the community with an expertise which they do not actually possess. This makes them competitors of the narrator for the reader's attention in the world presupposed by the text.

Such groups are a target in 4Q418 frags. 55 and 69 ii as well as in Mysteries (1Q27, 4Q299, 4Q300), which attacks magicians and their form of knowledge, employing terms otherwise used positively to refer to, from the narrator's point of view, non-standard and rejected forms of wisdom and understanding, e.g. Lady Folly in Proverbs who mirrors but differs from Wisdom. The targets of

34 See Mansfeld, "Bad Demiurge." 
these attacks have been identified as Hellenistic (non-Israelite) diviners and Babylonian magicians. ${ }^{35}$ Similarly, Lucretius, who as an Epicurean does not reject the existence of gods but regards them as not concerned with life on this earth in any way, reveals the expertise of priests as fraud in a famous passage (1.80-101) which alludes to the treatment of the sacrifice of Iphigeneia in several Greek and Roman tragedies. ${ }^{36}$ This sacrifice was intended to secure fair wind for the departure of the Greek fleet for Troy, but could only be expected to have this effect due to superstition.

A didactic narrative is more effective if it combines confirmatio and refutatio, and a narrative which is avowedly intended to help the reader navigate life and the world had better identify institutions which threaten to impair progress. Moreover, just as Lucretius does not directly refer to religious practice as it was observable around Italy in his day but alludes to a sacrificial scene in literary texts which were publicly performed, so Mysteries, viz. 1Q27 1 i 2-4, uses expressions in criticising Babylonian magicians which are also found in 1 En 6-11. What this suggests is that the critical engagement is with other texts, as well as an extra-textual reality. ${ }^{37}$

\subsection{The Fragment}

Another feature which our corpora share is that they occasionally integrate textual fragments of various descriptions, e.g. pieces of narrative which are in some sense intrusions in their context. When these carry with them traces of their original ideological intent, they become repurposed and marshalled for a different project. When they are not reminiscent of a particular competing and antecedently existent context and just stand out for being different, they are often apt to induce a different type of reader engagement compared to what precedes. In a text type which places tight constrains on possible reader responses this device stands out.

The end of Ecclesiastes is well-recognised for standing apart from the preceding text, which exhibits an unusual pessimism about the human condition, about the possibility to achieve happiness through actions with one's control, and about divine goodwill. Verses 12:3-8 describe a building inhabited by a household, situated in a village or town, but with a garden or open countryside nearby. The house and its inhabitants are old and declining. One attempt to align it with the preceding text is to interpret it as an allegory for the body

\footnotetext{
35 See Tigchelaar, "Wisdom and Counter-Wisdom," 191-93.

36 On the passage see Taylor, "Rationalism," 145-50.

37 On false prophecy see also Deut 13:2; on failed prophecy Lam 2:9.
} 
towards the end of a human life; ${ }^{38}$ on that reading it dovetails with the main body of the text, although it requires a different approach, viz. a metaphorical reading. But such alignment is harder to achieve when in 12:13 we are instructed to revere God and observe his commandments. The discontinuity with what precedes has led many to suspect that 12:13 is a later interpolation. Others think they can find ways of reconciling what precedes with the epilogue. ${ }^{39} \mathrm{In}$ any event, the reader is required to go back to what came earlier and examine if there are ways to read the text coherently. To guide the habituation of reader responses of this kind may be one purpose of this device. ${ }^{40}$

In his De rerum natura Lucretius has a need to provide rational explanations for natural phenomena, which one would otherwise explain with reference to divine intervention. At the end of book 2 (lines 1023-47) the narrator uses a form of argument which is firmly associated with the mindset he is opposing but then subverts, thereby making it stand out as belonging to a counternarrative while at the same time reappropriating it for his own favoured message. The intrusion at issue is a fragment which probably comes from Aristotle's lost dialogue De philosophia (although it does not matter for the construal of the meaning of the passage that it is recognised as such), ${ }^{41}$ which describes the wonder that would seize human beings who look for the first time at the night sky and see the various celestial bodies and the regularity of their movements. Yet as it is, so the argument, for us who are deeply familiar with these matters there is no sense of wonder left. Lucretius uses this reasoning to diminish our sense of wonder over, and quite possibly resistance to, a novel idea he himself is advancing: that there are other worlds in addition to our own.

\section{$5 \quad$ Conclusion}

We hope that the above discussion has revealed the potential for comparison between our two text corpora. To say that texts of such obvious pragmatic similarity are bound to tell their story in similar ways is not to diminish the pointit is to make it for us.

\footnotetext{
38 See Crenshaw, Ecclesiastes, 186.

39 For a view of strong discontinuity, see Longman, Ecclesiastes; for attempts to reconcile the epilogue, see Seow, Ecclesiastes, 390-96, or Fox, Time to Tear Down, 363-77.

$40 \quad$ See Krüger, Qoheleth, 212-15.

41 Compare Cicero, De natura deorum 2.95-96 = Aristotle frag. 13 Ross, and Chroust, "Lucretius."
} 
However, our aspirations go a little beyond mere comparison of what is rarely compared but ought to be. We believe that, for want of a better metaphor, the right distance from the object of study, i.e. the two text corpora, is important: if one gets too close, the temptation to find verbal correspondences and to lapse into an intertextual mode of reading will be strong; if one surveys the text from too great a distance, everything will resemble everything. To the extent that this study is intended to propose a model for dealing with our texts, it consists in this - inevitably rough — calibration of the right degree of magnification.

Rome already had a substantial Jewish community numbering in the tens of thousands in the middle of the first century $\mathrm{BCE}, 42$ and we can assume that it included many individuals who would have had the linguistic and cultural competence to perform a comparison of the kind we have proposed here. But the ideal first reader of our study is to be located elsewhere: Philo of Alexandria was steeped in both of the traditions we have drawn on here and sought to mediate between them. While there is no strong evidence suggesting that he was able to read Latin, he worked at a centre of Hellenistic learning and scholarship from which a number of the Greek works of Hellenistic didactic emanated, and engaged with the works of Hesiod. If one wanted to organise his oeuvre according to themes, many of the headings would overlap with the ones we have chosen to organise our material. ${ }^{43}$ When he visited the court of Caligula as a diplomat, he may just have felt a need to identify topics suitable for conversation during the semi-official parts of his schedule.

We have tried to think about exemplarity by engaging the notion of paradigm or character and how that ideal state is constructed. We have done that by isolating some elements of what constitutes an exemplar, namely, creation, law, form and figure, or sage. We tried to create an opportunity to think across traditions with texts that are remarkably similar. Surprisingly, these connections are understudied. In this concluding paragraph we want to take one more step. Could there have been conversations across religious and cultural boundaries that enabled connections between communities? Might we imagine readers who could have put these texts together and thought with each other about what it means to live in accordance with nature or how to give an account of creation? We set out a pathway for the comparative study of antiquity as an alternative to comparative work that presupposes dependency and direct influence.

\footnotetext{
42 See Solin, "Juden und Syrer," 698-701.

43 Witness Lévy, "Philo"; and see Najman, Seconding Sinai, 70-107.
} 


\section{Bibliography}

Batstone, W. "Virgilian Didaxis: Value and Meaning in the Georgics." In The Cambridge Companion to Virgil, ed. C. Martindale and F. Mac Góráin (Cambridge: Cambridge University Press, 2019; second edition), 193-215.

Collins, J.J.Jewish Wisdom in the Hellenistic Age (Edinburgh: T\&T Clark, 1997).

Chroust, A.H. “Lucretius, De rerum natura II, 1024-42. A Possible Fragment of Aristotle's On Philosophy." Symbolae Osloenses 51 (1976), 95-103.

Cornell, C.R. "God and the Sea in Job 38." Journal of Hebrew Scriptures 12 (2012), 1-15.

Crenshaw, J.L. Ecclesiastes: A Commentary (Philadelphia: Westminster, 1987).

Crenshaw, J.L. Old Testament Wisdom: An Introduction (Louisville: Westminster, 2010).

Day, J. God's Conflict with the Dragon and the Sea: Echoes of a Canaanite Myth in the Old Testament (Cambridge: Cambridge University Press, 1985).

Fowler, D.P. "Lucretius and Politics." In Philosophia Togata I, ed. M.T. Griffin and J. Barnes (Oxford: Oxford University Press, 1989), 120-50.

Fowler, D.P. "The Didactic Plot.” In Matrices of Genre: Authors, Canons, and Society, ed. M. Depew and D. Obbink (Cambridge, MA: Harvard University Press, 2000), 201-19. Fox, M.V. A Time to Tear Down and a Time to Build Up: A Rereading of Ecclesiastes (Eugene: Wipf, 1999).

Fox, M.V. Proverbs 10-31 (New Haven: Yale Univesity Press, 2009).

Kerkhecker, A. Callimachus' Book of Iambi (Oxford: Oxford University Press, 1999).

Kister, M. "Wisdom Literature and Its Relation to Other Genres: From Ben Sira to Mysteries." In Sapiential Perspectives: Wisdom Literature in Light of the Dead Sea Scrolls, ed. J.J. Collins, G.E. Sterling, and R.A. Clements (Leiden: Brill, 2004), 13-47.

Kister, M. "Wisdom Literature from Qumran." In The Qumran Scrolls and Their World, vol 1, ed. Kister (Jerusalem: Yad Ben-Zvi, 20o9), 299-319. [Hebrew]

Kruschwitz, P. and M. Schumacher. Das vorklassische Lehrgedicht der Römer (Heidelberg: Winter, 2005).

Kynes, W. An Obituary for "Wisdom Literature": The Birth, Death, and Intertextual Reintegration of a Biblical Corpus (Oxford: Oxford, 2019).

Lévy, C. "Philo of Alexandria." In The Stanford Encyclopedia of Philosophy (Spring 2018 Edition), ed. E.N. Zalta, URL $=<$ https://plato.stanford.edu/archives/spr2018/ entries/philo/>.

Lange, A. Weisheit und Prädestination: Weisheitliche Urordnung und Prädestination in den Textfunden von Qumran (Leiden: Brill, 1995).

Longman, T. The Book of Ecclesiastes (Grand Rapids: Eerdmans, 1998).

Mansfeld, J. "Bad World and Demiurge: A 'Gnostic' Motif from Parmenides and Empedocles to Lucretius and Philo." In Studies in Gnosticism and Hellenistic Religions presented to Gilles Quispel on the Occasion of his 65th Birthday, ed. R. van den Broek and M.J. Vermaseren (Leiden: Brill, 1981), 261-314. 
Mitis, P. "Committing Philosophy on the Reader: Didactic Coercion and Reader Autonomy in De rerum natura." In Mega Nepios: il destinario nell'epos didascalico, Materiali e discussioni per l'analisi dei testi classici, ed. A. Schiesaro, P. Mitsis, and J. Strauss Clay (Pisa: Giardini, 1993), 111-28.

Najman, H. Seconding Sinai: The Development of Mosaic Discourse in Second Temple Judaism (Leiden: Brill, 2003).

Najman, H. "The Idea of Biblical Genre: From Discourse to Constellation." In Prayer and Poetry in the Dead Sea Scrolls and Related Literature, ed. J. Penner, K.M. Penner, and C. Wassen (Leiden: Brill, 2011), 308-21.

Najman, H. "Jewish Wisdom in the Hellenistic Period: Towards the Study of a Semantic Constellation." In Is There a Text in This Cave? Studies in the Textuality of the Dead Sea Scrolls in Honour of George J. Brooke, ed. A. Feldman, M. Cioată, and C. Hempel (Leiden: Brill, 2017), 459-72.

Newman, J. "Hybridity, Hydrology, and Hidden Transcript: Sirach 24 and the Judean Encounter with Ptolemaic Isis Worship." In Jewish Cultural Encounters in the Ancient Mediterranean and Near Eastern World, ed. M. Popović, M. Schoonover, and M. Vandenberghe (Leiden: Brill, 2017), 157-76.

Norden, E. Agnostos Theos: Untersuchungen zur Formengeschichte religiöser Rede (Darmstadt: Wissenschaftliche Buchgesellschaft, 1956).

Schiesaro, A., P. Mitsis, and J. Strauss Clay. Mega Nepios: il destinario nell'epos didascalico (Pisa: Giardini, 1993).

Schiesaro, A. "Lucretius' On the Nature of Things: Eschatology in an Age of Anxiety." In Eschatology in Antiquity, ed. H. Marlow, K. Pollmann, and H. van Noorden (London: Routledge, 2020).

Schiesaro, A. "Lucretius' Apocalyptic Imagination" (forthcoming).

Seow, C.L. Ecclesiastes (New Haven: Yale University Press, 1997).

Solin, H. "Juden und Syrer in der römischen Welt." Aufstieg und Niedergang der römischen Welt II.29.2 (1983), 587-789.

Stewart, A. Poetic Ethics in Proverbs: Wisdom Literature and the Shaping of the Moral Self (New York: Cambridge, 2016).

Taylor, B. "Rationalism and the Theatre in Lucretius." Classical Quarterly 66 (2016), $140-54$.

Tigchelaar, E. "Wisdom and Counter-Wisdom in 4QInstruction, Mysteries and 1 Enoch." In The Early Enoch Literature, ed. G. Boccaccini and J.J. Collins (Leiden: Brill, 2007), 177-93.

Van Wolde, E. "Separation and Creation in Genesis 1 and Psalm 104, A Continuation of the Discussion of the Verb ברא." Vetus Testamentum 67 (2017), 611-47.

Volk, K. The Poetics of Latin Didactic: Lucretius, Vergil, Ovid, Manilius (Oxford: Oxford University Press, 2002). 
Volk, K. Manilius and his Intellectual Background (Oxford: Oxford University Press, 2009).

Von Rad, G. Wisdom in Israel (Harrisburg, PA: Trinity Press International, 1972).

Weeks, S. "Is 'Wisdom Literature' a Useful Category?" In Tracing Sapiential Traditions in Ancient Judaism, ed. H. Najman, J.S. Rey, and E. Tigchelaar (Leiden: Brill, 2016).

West, M.L. Hesiod, Works and Day (Oxford: Oxford University Press, 1978).

Wright, B.G. "From Generation to Generation: The Sage as Father in Early Jewish Literature." In Biblical Traditions in Transmission, ed. C. Hempel and J.M. Lieu (Leiden: Brill, 2006), 309-32.

Wright, B.G. "The Use and Interpretation of Biblical Tradition in Ben Sira's Praise of the Ancestors." In Studies in the Book of Ben Sira, ed. G.G. Xeravits and J. Zsengellér (Leiden: Brill, 2008), 183-207.

Wright, B.G. "Ben Sira and Hellenistic Literature in Greek." In Tracing Sapiential Traditions in Ancient Judaism, ed. H. Najman, J.S. Rey, and E. Tigchelaar (Leiden: Brill, 2016), 71-88.

\section{Translations and Editions}

Pietersma, A., and B.G. Wright, eds. A New English Translation of the Septuagint and the Other Greel Translations Traditionally Included under that Title (New York: Oxford University Press, 2007).

Lucretius, On the Nature of Things. Translated by W.H.D. Rouse. Revised by M.F. Smith (Cambridge, MA: Harvard University Press, 1924).

Manilius, Astronomica. Translated by G.P. Goold (Cambridge, MA: Harvard University Press, 1977).

Schuller, E.M. and C.A. Newsom, The Hodayot (Thanksgiving Psalms): A Study Edition of ${ }_{1 Q H^{a}}$ (Atlanta: Society of Biblical Literature, 2012).

Virgil, Eclogues. Georgics. Aeneid: Books 1-6. Translated by H.R. Fairclough. Revised by G.P. Goold (Cambridge, MA: Harvard University Press, 1916).

Ziegler, J., ed. Sapientia Salomonis (Göttingen: Vandenhoeck \& Ruprecht, 1962).

Ziegler, J., ed. Sapientia Iesu Filii Sirach (Göttingen: Vandenhoeck \& Ruprecht, 1965). 